University of Nebraska - Lincoln

DigitalCommons@University of Nebraska - Lincoln

Faculty Papers and Publications in Animal

Science

Animal Science Department

2-3-2005

\title{
Lack of evidence for cytoplasmic effects for four traits of Polypay sheep
}

L. Dale Van Vleck

University of Nebraska-Lincoln, dvan-vleck1@unl.edu

Kathryn J. Hanford

University of Nebraska, kathy.hanford@unl.edu

G. D. Snowder

USDA-ARS, U.S. Meat Animal Research Center

Follow this and additional works at: https://digitalcommons.unl.edu/animalscifacpub

Part of the Animal Sciences Commons

Van Vleck, L. Dale; Hanford, Kathryn J.; and Snowder, G. D., "Lack of evidence for cytoplasmic effects for four traits of Polypay sheep" (2005). Faculty Papers and Publications in Animal Science. 213.

https://digitalcommons.unl.edu/animalscifacpub/213

This Article is brought to you for free and open access by the Animal Science Department at DigitalCommons@University of Nebraska - Lincoln. It has been accepted for inclusion in Faculty Papers and Publications in Animal Science by an authorized administrator of DigitalCommons@University of Nebraska - Lincoln. 


\title{
Lack of evidence for cytoplasmic effects for four traits of Polypay sheep ${ }^{1}$
}

\author{
L. D. Van Vleck $\dagger^{2}$, K. J. Hanford $\dagger^{3}$, and G. D. Snowder \\ ARS, USDA, U.S. Meat Animal Research Center, †Lincoln 68583-0908 and $¥$ Clay Center, NE 68933
}

\begin{abstract}
Analyses of birth and weaning weights, fleece weights of ewes, and number born per litter of Polypay sheep collected at the U.S. Sheep Experimental Station from 1978 through 1998, confirmed previous analyses of three other dual-purpose breeds that cytoplasmic effects do not contribute to variation in these four traits. In general, estimates of genetic parameters that would be needed for national genetic evaluation were similar to previous estimates for Columbia, Rambouillet, and Targhee sheep, although estimates of direct heritability for Polypay were somewhat less for birth weight, slightly greater for weaning weight, sig-
\end{abstract}

nificantly greater for fleece weight, and the same for number born as for those three breeds. For birth weight only, evidence was found for important dam $\times$ year or dam $\times$ number born interactions, which are essentially litter effects, as was found for the other dual-purpose breeds. There were $11,896,11,104,7,748$, and 7,831 records for birth and weaning weights, fleece weight, and number born per litter, with 255 to 316 sires of animals with records. There were 260 and 261 cytoplasmic lines for fleece weight and number born, and 861 and 882 for weaning and birth weights.

Key Words: Breed Comparisons, Cytoplasmic Inheritance, Heritability, Maternal Effects

(C)2005 American Society of Animal Science. All rights reserved.

J. Anim. Sci. 2005. 83:552-556

\section{Introduction}

Recent studies have failed to show variation in economically important traits due to cytoplasmic effects in Suffolk sheep for growth traits (Maniatis and Pollot, 2002) and for four representative traits of Targhee (Van Vleck et al., 2003), Columbia (Hanford et al., 2003), and Rambouillet (Snowder et al., 2004) sheep. These papers have summarized the biology of mitochondria, which are thought to be responsible for cytoplasmic effects. Limited studies of cytoplasmic effects for beef and dairy cattle have, in general, also reported that variation due to cytoplasmic effects is small (see review by Gibson et al., 1997).

Columbia, Targhee, and Rambouillet are dual-purpose breeds of sheep that all trace back to Rambouillet ewes, as do Polypay sheep, and thus might represent different samples of Rambouillet cytoplasm. The studies involving Columbia, Rambouillet, and Targhee sheep all reported interactions of dam and year of birth,

\footnotetext{
${ }^{1}$ Published as Paper No. 14826, Journal Ser., Nebraska Agric. Res. Div., Univ. of Nebraska, Lincoln 68583-0908.

${ }^{2}$ Correspondence: A218 Anim. Sci., Univ. of Nebraska, Lincoln 68583-0908 (phone: 402-472-6010; fax: 402-472-6362; e-mail: lvanvleck@unlnotes.unl.edu).

${ }^{3}$ Current address: Dept. of Anim. Sci., Univ. of Nebraska, Lincoln 68583-0908.

Received November 4, 2004.

Accepted December 16, 2004.
}

dam with number born, and dam with sire genotype for birth weight. Those studies, however, did not find variation due to those interactions for the other three representative traits: weaning weight, fleece weight, and number born.

The Polypay is a composite breed developed at the U.S. Sheep Experiment Station (near Dubois, Idaho) in the early 1970s from crosses of Finnsheep rams by Rambouillet ewes and polled Dorset rams by Targhee ewes followed by matings between these crosses (Hulet et al., 1984). One purpose for developing this composite was to increase prolificacy at the expense of fleece weight, but with minimal effect on weaning weight. Although the cytoplasm traces to the Rambouillet, one purpose of this study was to determine whether that cytoplasm in a different genetic background (genes from Finn sheep and polled Dorset sheep) accounts for any variation in the four representative traits studied in the three other dual-purpose breeds, which also were from populations at the U.S. Sheep Experiment Station. Another purpose was to determine whether the interactions of dam with year, sire, and number born were as important for birth weight of Polypay sheep as with the other breeds.

\section{Materials and Methods}

Records were available for Polypay only since 1977 for birth and weaning weights and since 1978 for fleece weight and litter size at birth. Ercanbrack and Knight 
Table 1. Summary of number of records and of levels by factor for four traits of Polypay sheep ${ }^{a}$

\begin{tabular}{lcccc}
\hline \hline Item & $\begin{array}{c}\text { Birth } \\
\text { weight }\end{array}$ & $\begin{array}{c}\text { Wean } \\
\text { weight }\end{array}$ & $\begin{array}{c}\text { Fleece } \\
\text { weight }\end{array}$ & $\begin{array}{c}\text { No. } \\
\text { born }\end{array}$ \\
\hline Records & 11,896 & 11,104 & 7,748 & 7,831 \\
Mean weight, kg & 4.05 & 33.8 & 3.49 & 1.78 \\
SD weight, kg & 0.78 & 5.8 & 0.76 & 0.85 \\
Animals with records & 11,896 & 11,104 & 2,564 & 2,581 \\
Sires & 316 & 316 & 255 & 255 \\
Dams & 2,877 & 2,843 & 1,242 & 1,249 \\
Cytoplasmic line & 882 & 861 & 260 & 261 \\
Dam $\times$ year & 7,293 & 7,207 & 2,236 & 2,246 \\
Sire $\times$ dam & 7,276 & 7,190 & 2,231 & 2,241 \\
Sire $\times$ cytoplasmic line & 5,810 & 5,742 & 2,045 & 2,054 \\
Dam $\times$ No. born & 4,536 & - & - & - \\
\hline
\end{tabular}

${ }^{a}$ Number of animals in pedigree file $=13,550$; number of genetic groups $=56$, up to nine generations to founder dam of cytoplasmic line.

(1998) have described general flock management. The numbers of records, sires, dams, and cytoplasmic sources are given in Table 1. Cytoplasmic lines were determined by tracing all animals back through the female line of descent to unique and assumed unrelated females.

The means in Table 1 indicate approximately half a lamb more born per litter for Polypay compared with previous analyses with Columbia, Rambouillet, and Targhee breeds, which reflects the inclusion of Finnsheep in the composite. Fleece weight, however, was 1.2 to $1.8 \mathrm{~kg}$ less than for the Columbia, Rambouillet, and Targhee. Weaning weight $(120 \mathrm{~d})$ was similar for the four breeds, although birth weight was 0.63 to 0.85 $\mathrm{kg}$ less for Polypay than for the other three breeds. These differences from Columbia, Rambouillet, and Targhee indicate a somewhat different genetic background for expression of effects in the cytoplasm of Polypay sheep.

Table 2 lists fixed factors and the number of levels for those factors in the statistical models for the four traits. Random factors (and the direct-maternal genetic covariance) in statistical models are indicated in Tables

Table 2. Number of levels for fixed factors in models for analysis of four traits (birth weight, wean weight, fleece weight, number born) of Polypay sheep

\begin{tabular}{lcccc}
\hline \hline Factor & $\begin{array}{c}\text { Birth } \\
\text { weight }\end{array}$ & $\begin{array}{c}\text { Wean } \\
\text { weight }\end{array}$ & $\begin{array}{c}\text { Fleece } \\
\text { weight }\end{array}$ & $\begin{array}{c}\text { No. } \\
\text { born }\end{array}$ \\
\hline Year & 22 & 22 & 21 & 21 \\
Age of dam (ewe) & 10 & 10 & $(10)$ & $(10)$ \\
Gender & 2 & 3 & - & - \\
Type of birth (TB) & 5 & - & - & - \\
TB and rearingb & - & 8 & - & - \\
No. weaned & - & - & 4 & - \\
Calendar day & - & - & COV $^{\mathrm{c}}$ & - \\
\hline
\end{tabular}

${ }^{a}$ Number born in litter.

${ }^{\mathrm{b}}$ Combinations of type of birth and number reared.

${ }^{\mathrm{c}} \mathrm{COV}=$ day of year shorn, as a linear covariate.
$3,4,5$, and 6 of results for the four traits. The directmaternal genetic covariance was dropped from models for the female traits. Because various selection experiments had involved sheep in this flock, genetic groups (Westell et al., 1988) were used to account for that selection (Hanford, 2001). Groups were defined by year of birth of foundation animals in the pedigree, with different groups for the unknown sires and dams of foundation animals. Including group effects did not change estimates of variance components greatly. Therefore, additions and subtractions of random factors to or from the statistical model were made only to the model without group effects. The genotype $\times$ year interaction was represented by the dam $\times$ year component of variance rather than the more usual sire $\times$ year component because sires were not used more than $1 \mathrm{yr}$.

A derivative-free algorithm for REML (Smith and Graser, 1986) was used to estimate components of variance with the MTDFREML programs (Boldman et al., 1995). Standard errors for genetic parameters were obtained at convergence using the delta method and the average information matrix (e.g., Dodenhoff et al., 1998). Differences in twice the natural logarithm of the likelihood given the data were used to calculate the likelihood ratio test (LRT) to compare the models. Degrees of freedom were the differences in number of random factors in the models. Tests were based on the full model and on nested reduced models.

\section{Results and Discussion}

In general, the results were similar to those previously reported for the Columbia, Rambouillet, and Targhee dual-purpose breeds; therefore, the discussion will be brief.

For birth weight (Table 3), the estimates of variance due to cytoplasmic effects were near zero for any model including cytoplasmic effects. The likelihood ratio test for the usual model with and without cytoplasmic effects was 0.00 . In contrast with results previously re- 
Table 3. Estimates of genetic parameters for birth weight with 17 models with standard errors (SE) for complete model (Polypay) ${ }^{\mathrm{a}, \mathrm{b}}$

\begin{tabular}{|c|c|c|c|c|c|c|c|c|c|c|}
\hline \multicolumn{11}{|c|}{ Parameters } \\
\hline$a^{2}$ & $\mathrm{r}_{\mathrm{am}}$ & $\mathrm{m}^{2}$ & $\mathrm{p}^{2}$ & $c^{2}$ & $d y^{2}$ & $\mathrm{dn}^{2}$ & $\mathrm{sd}^{2}$ & $\mathrm{sc}^{2}$ & $\mathrm{e}^{2}$ & $2 \log \mathrm{L}$ \\
\hline \multicolumn{11}{|c|}{ Models with genetic groups } \\
\hline 0.17 & 0.19 & 0.20 & 0.10 & - & - & - & - & - & 0.50 & 0.00 \\
\hline 0.16 & 0.21 & 0.19 & 0.08 & 0.00 & 0.10 & - & 0.00 & 0.02 & 0.41 & $137.81^{\mathrm{c}}$ \\
\hline \multicolumn{11}{|c|}{ Models without genetic groups } \\
\hline 0.17 & 0.15 & 0.20 & 0.10 & - & - & - & - & - & 0.50 & 0.00 \\
\hline 0.17 & 0.15 & 0.20 & 0.10 & 0.00 & - & - & - & - & 0.50 & $0.00^{\mathrm{d}}$ \\
\hline 0.15 & 0.17 & 0.19 & 0.08 & - & 0.13 & - & - & - & 0.41 & $135.24^{\mathrm{d}}$ \\
\hline 0.14 & 0.15 & 0.30 & - & - & 0.13 & - & - & - & 0.40 & $109.28^{\mathrm{d}}$ \\
\hline 0.17 & 0.15 & 0.19 & 0.06 & - & - & 0.08 & - & - & 0.47 & $74.73^{\mathrm{d}}$ \\
\hline 0.15 & 0.18 & 0.19 & 0.06 & - & 0.10 & 0.05 & - & - & 0.41 & $151.77^{\mathrm{d}}$ \\
\hline 0.15 & 0.17 & 0.19 & 0.08 & - & - & - & 0.12 & - & 0.41 & $132.04^{\mathrm{d}}$ \\
\hline 0.16 & 0.17 & 0.19 & 0.09 & - & - & - & - & 0.09 & 0.44 & $103.56^{\mathrm{d}}$ \\
\hline 0.15 & 0.17 & 0.19 & 0.08 & 0.00 & - & - & 0.12 & - & 0.41 & $132.12^{\mathrm{d}}$ \\
\hline 0.16 & 0.18 & 0.19 & 0.09 & 0.00 & - & - & - & 0.09 & 0.44 & $103.56^{\mathrm{d}}$ \\
\hline 0.15 & 0.18 & 0.19 & 0.08 & 0.00 & - & - & 0.10 & 0.03 & 0.41 & $137.09^{\mathrm{d}}$ \\
\hline 0.15 & 0.18 & 0.19 & 0.08 & - & 0.12 & - & 0.00 & - & 0.41 & $135.22^{\mathrm{d}}$ \\
\hline 0.15 & 0.17 & 0.19 & 0.06 & - & 0.10 & 0.05 & 0.00 & - & 0.41 & $151.77^{\mathrm{d}}$ \\
\hline 0.15 & 0.18 & 0.19 & 0.09 & 0.00 & 0.10 & - & 0.00 & 0.03 & 0.41 & $140.10^{\mathrm{d}}$ \\
\hline 0.15 & 0.17 & 0.19 & 0.06 & 0.00 & 0.10 & 0.05 & 0.00 & 0.00 & 0.41 & $151.77^{\mathrm{d}}$ \\
\hline (0.022 & 0.107 & 0.027 & 0.019 & 0.006 & 0.100 & 0.012 & 0.101 & 0.011 & 0.018 & $\mathrm{SE})^{\mathrm{b}}$ \\
\hline
\end{tabular}

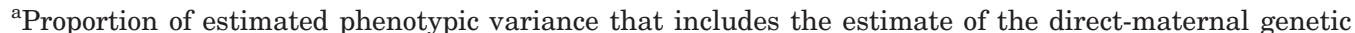
covariance: $\mathrm{a}^{2}=$ direct genetic; $\mathrm{r}_{\mathrm{am}}=$ direct-maternal genetic correlation; $\mathrm{m}^{2}=$ maternal genetic; $\mathrm{p}^{2}=$ maternal permanent environmental; $\mathrm{c}^{2}=$ cytoplasmic line; $\mathrm{dy}^{2}=$ dam by year; $\mathrm{dn}^{2}=$ dam by number born; $\mathrm{sd}^{2}=$ sire by dam; $\mathrm{sc}^{2}=$ sire by cytoplasmic line; $\mathrm{e}^{2}=$ temporary environmental. Phenotypic variance: 0.4208 to 0.4390 $\mathrm{kg}^{2}$.

${ }^{\mathrm{b}}$ Model not including genetic groups.

${ }^{\mathrm{c}}$ Difference in $2 \mathrm{log}$ likelihood from usual model with genetic groups in model.

${ }^{\mathrm{d} D}$ Difference in $2 \log$ likelihood from usual model with genetic groups not in model.

ported for Columbia (Hanford et al., 2003), Rambouillet (Snowder et al., 2004), and Targhee (Van Vleck et al., 2003) breeds, the estimate of direct heritability was smaller ( 0.15 vs. 0.25$)$, the estimate of maternal heritability was similar (0.20), but the estimate of the directmaternal genetic correlation was somewhat greater

Table 4. Estimates of genetic parameters for weaning weight with 11 models with standard errors (SE) for complete model (Polypay) ${ }^{\mathrm{a}, \mathrm{b}}$

\begin{tabular}{|c|c|c|c|c|c|c|c|c|c|}
\hline \multicolumn{10}{|c|}{ Parameters } \\
\hline$a^{2}$ & $\mathrm{r}_{\mathrm{am}}$ & $\mathrm{m}^{2}$ & $\mathrm{p}^{2}$ & $c^{2}$ & $d y^{2}$ & $\mathrm{sd}^{2}$ & $\mathrm{sc}^{2}$ & $\mathrm{e}^{2}$ & $2 \log \mathrm{L}$ \\
\hline \multicolumn{10}{|c|}{ Models with genetic groups } \\
\hline 0.25 & -0.17 & 0.09 & 0.05 & - & - & - & - & 0.65 & 0.00 \\
\hline 0.24 & -0.18 & 0.09 & 0.04 & 0.00 & 0.00 & 0.00 & 0.02 & 0.63 & $5.09^{c}$ \\
\hline \multicolumn{10}{|c|}{ Models without genetic groups } \\
\hline 0.21 & -0.26 & 0.10 & 0.04 & - & - & - & - & 0.69 & 0.00 \\
\hline 0.21 & -0.27 & 0.10 & 0.04 & 0.00 & - & - & - & 0.69 & $0.00^{\mathrm{d}}$ \\
\hline 0.21 & -0.27 & 0.10 & 0.04 & - & 0.00 & - & - & 0.69 & $0.00^{\mathrm{d}}$ \\
\hline 0.21 & -0.27 & 0.10 & 0.04 & - & - & 0.00 & - & 0.69 & $0.00^{\mathrm{d}}$ \\
\hline 0.21 & -0.27 & 0.10 & 0.04 & - & - & - & 0.03 & 0.67 & $6.65^{\mathrm{d}}$ \\
\hline 0.21 & -0.27 & 0.10 & 0.04 & 0.00 & - & - & 0.03 & 0.67 & $6.65^{\mathrm{d}}$ \\
\hline 0.21 & -0.27 & 0.10 & 0.04 & 0.00 & - & 0.00 & 0.03 & 0.67 & $6.65^{\mathrm{d}}$ \\
\hline 0.21 & -0.27 & 0.10 & 0.04 & 0.00 & 0.00 & 0.00 & 0.03 & 0.67 & $6.65^{\mathrm{d}}$ \\
\hline$(0.030$ & 0.110 & 0.021 & 0.013 & 0.005 & 0.170 & 0.170 & 0.014 & 0.025 & $\mathrm{SE})^{\mathrm{b}}$ \\
\hline
\end{tabular}

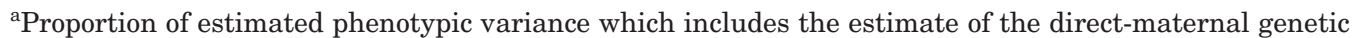
covariance: $\mathrm{a}^{2}=$ direct genetic; $\mathrm{r}_{\mathrm{am}}=$ direct-maternal genetic correlation; $\mathrm{m}^{2}=$ maternal genetic; $\mathrm{p}^{2}=$ maternal permanent environmental; $\mathrm{c}^{2}=$ cytoplasmic line; $\mathrm{dy}^{2}=$ dam by year; $\mathrm{sd}^{2}=$ sire by dam; $\mathrm{sc}^{2}=\operatorname{sire}$ by cytoplasmic line; $\mathrm{e}^{2}=$ temporary environmental. Phenotypic variance: 21.76 to $22.29 \mathrm{~kg}^{2}$.

${ }^{\mathrm{b}}$ Model not including genetic groups.

${ }^{\mathrm{c} D i f f e r e n c e ~ i n ~} 2 \log$ likelihood from usual model with genetic groups in model.

${ }^{\mathrm{d} D i f f e r e n c e ~ i n ~} 2 \log$ likelihood from usual model with genetic groups not in model. 
Table 5. Estimates of genetic parameters for fleece weight with eight models with standard errors (SE) for complete model (Polypay) ${ }^{\mathrm{a}, \mathrm{b}}$

\begin{tabular}{|c|c|c|c|c|c|c|c|c|c|}
\hline \multicolumn{10}{|c|}{ Parameters } \\
\hline $\mathrm{a}^{2}$ & $\mathrm{~m}^{2}$ & $\mathrm{p}_{\mathrm{m}}^{2}$ & $\mathrm{p}_{\mathrm{a}}^{2}$ & $c^{2}$ & $\mathrm{dy}^{2}$ & $\mathrm{sd}^{2}$ & $\mathrm{sc}^{2}$ & $\mathrm{e}^{2}$ & $2 \log \mathrm{L}$ \\
\hline \multicolumn{10}{|c|}{ Models with genetic groups } \\
\hline 0.66 & 0.03 & 0.00 & 0.03 & - & - & - & - & 0.28 & 0.00 \\
\hline 0.65 & 0.03 & 0.00 & 0.00 & 0.00 & 0.00 & 0.04 & 0.00 & 0.28 & $1.46^{\mathrm{c}}$ \\
\hline \multicolumn{10}{|c|}{ Models without genetic groups } \\
\hline 0.67 & 0.03 & 0.00 & 0.02 & - & - & - & - & 0.28 & 0.00 \\
\hline 0.70 & - & 0.01 & 0.02 & - & - & - & - & 0.28 & $-9.07^{\circ}$ \\
\hline 0.69 & - & - & 0.03 & - & - & - & - & 0.28 & $-10.83^{\mathrm{C}}$ \\
\hline 0.66 & 0.03 & - & 0.00 & - & 0.03 & - & - & 0.28 & $2.46^{\mathrm{C}}$ \\
\hline 0.66 & 0.03 & - & - & - & 0.03 & - & - & 0.28 & $2.46^{\mathrm{C}}$ \\
\hline 0.67 & 0.03 & - & 0.02 & - & - & - & 0.00 & 0.28 & $0.00^{\mathrm{c}}$ \\
\hline 0.66 & 0.03 & - & 0.00 & - & 0.03 & - & 0.00 & 0.28 & $2.46^{\mathrm{C}}$ \\
\hline 0.66 & 0.03 & 0.00 & 0.00 & 0.00 & 0.03 & 0.00 & 0.00 & 0.28 & $2.46^{\mathrm{C}}$ \\
\hline$(0.033$ & 0.016 & 0.013 & 0.034 & 0.010 & 0.155 & 0.156 & 0.030 & 0.010 & $\mathrm{SE})^{\mathrm{b}}$ \\
\hline
\end{tabular}

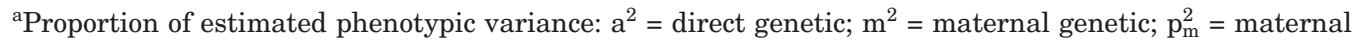
permanent environmental; $p_{a}^{2}=$ animal permanent environmental; $c^{2}=$ cytoplasmic line; $d^{2}{ }^{2}=$ dam by year; $\mathrm{sd}^{2}=$ sire by dam; $\mathrm{sc}^{2}=$ sire by cytoplasmic line; $\mathrm{e}^{2}=$ temporary environmental. Phenotypic variance: 0.5627 to $0.5793 \mathrm{~kg}^{2}$.

${ }^{\mathrm{b}}$ Model not including genetic groups.

${ }^{\mathrm{c}}$ Difference in $2 \log$ likelihood from usual model with genetic groups in model.

${ }^{\mathrm{d} D i f f e r e n c e ~ i n ~} 2 \log$ likelihood from usual model with genetic groups not in model.

( 0.17 vs. -0.05 to 0.11 ). The estimate of fraction of variance due to maternal permanent environmental effects was similar ( 0.06 vs. 0.02 to 0.08 ). Estimates of fractions of phenotypic variance due to dam $\times$ year and dam $\times$ number born were similar to estimates for the Columbia, Rambouillet, and Targhee breeds $(0.10$ and 0.05 vs. 0.06 to 0.08 and 0.04 ). For models with other interactions, estimates of fraction of variance due to sire $\times$ dam interactions were zero, whereas with the other three breeds estimates were small but somewhat greater (0.03 to 0.05). As with the other breeds, including effects in addition to those in the usual model (direct and maternal genetic and maternal permanent environmental effects), did not affect estimates of the genetic parameters (heritabilities and genetic correlation). A complete explanation for the significance of the interactions with dam (year and number born) is still lacking, although dam $\times$ year effects are equivalent to litter effects, which were reported to be important by Al-Shorepy and Notter (1998).

Results were quite different for weaning weight (120 d) compared with those for birth weight (Table 4). The

Table 6. Estimates of genetic parameters for number born with eight models with standard errors (SE) for complete model (Polypay) ${ }^{\mathrm{a}, \mathrm{b}}$

\begin{tabular}{|c|c|c|c|c|c|c|c|c|c|}
\hline \multicolumn{10}{|c|}{ Parameters } \\
\hline$a^{2}$ & $\mathrm{~m}^{2}$ & $\mathrm{p}_{\mathrm{m}}^{2}$ & $\mathrm{p}_{\mathrm{a}}^{2}$ & $c^{2}$ & $\mathrm{dy}^{2}$ & $\mathrm{sd}^{2}$ & $\mathrm{sc}^{2}$ & $\mathrm{e}^{2}$ & $2 \log \mathrm{L}$ \\
\hline \multicolumn{10}{|c|}{ Models with genetic groups } \\
\hline 0.11 & 0.00 & 0.00 & 0.00 & - & - & - & - & 0.89 & 0.00 \\
\hline 0.09 & 0.00 & 0.00 & 0.00 & 0.00 & 0.00 & 0.02 & 0.00 & 0.89 & $2.70^{\mathrm{c}}$ \\
\hline \multicolumn{10}{|c|}{ Models without genetic groups } \\
\hline 0.09 & 0.00 & 0.00 & 0.02 & - & - & - & - & 0.89 & 0.00 \\
\hline 0.08 & - & 0.00 & 0.00 & - & 0.03 & - & - & 0.89 & $4.86^{\mathrm{d}}$ \\
\hline 0.08 & - & - & 0.00 & - & 0.03 & - & 0.00 & 0.89 & $4.86^{\mathrm{d}}$ \\
\hline 0.08 & - & - & 0.00 & - & 0.03 & - & - & 0.89 & $4.86^{\mathrm{d}}$ \\
\hline 0.09 & - & - & 0.00 & - & - & - & 0.02 & 0.89 & $3.33^{\mathrm{d}}$ \\
\hline 0.08 & 0.00 & 0.00 & 0.00 & 0.00 & 0.00 & 0.03 & 0.00 & 0.89 & $4.91^{\mathrm{d}}$ \\
\hline$(0.017$ & 0.009 & 0.011 & 0.024 & 0.004 & 0.196 & 0.196 & 0.024 & 0.012 & $\mathrm{SE})^{\mathrm{b}}$ \\
\hline
\end{tabular}

${ }^{\text {a} P r o p o r t i o n ~ o f ~ e s t i m a t e d ~ p h e n o t y p i c ~ v a r i a n c e: ~} \mathrm{a}^{2}=$ direct genetic; $\mathrm{m}^{2}=$ maternal genetic; $\mathrm{p}_{\mathrm{m}}^{2}=$ maternal permanent environmental; $\mathrm{p}_{\mathrm{a}}^{2}=$ animal permanent environmental; $\mathrm{c}^{2}=$ cytoplasmic line; $\mathrm{dy}^{2}=$ dam by year; $\mathrm{sd}^{2}=$ sire by dam; $\mathrm{sc}^{2}=$ sire by cytoplasmic line; $\mathrm{e}^{2}=$ temporary environmental. Phenotypic variance: 0.5619 to 0.5659 .

${ }^{\mathrm{b}}$ Model not including genetic groups.

${ }^{\mathrm{c} D i f f e r e n c e}$ in $2 \log$ likelihood from usual model with genetic groups in model.

${ }^{\mathrm{d} D i f f e r e n c e ~ i n ~} 2 \log$ likelihood from usual model with genetic groups not in model. 
results were, however, similar to those for the other three dual-purpose breeds. The estimates of variance due to the interactions with dam were uniformly near zero. In contrast, although not large, the fraction of variance due to sire by cytoplasmic origin was $0.03 \mathrm{vs}$. 0.00 for the other breeds. The 0.03 was significant based on the LRT and also as indicated by the standard error of the estimate. Estimates of maternal heritability were similar (0.10) for the four breeds but the estimate of direct heritability for Polypay of 0.21 was slightly greater than for the other breeds (0.14 to 0.18$)$. The direct-maternal genetic correlation was considerably more negative for Polypay ( -0.26 vs. -0.02 to 0.30 ).

Estimates of parameters for fleece weight are in Table 5. The estimate of direct heritability was large and somewhat greater than estimates for the other three breeds ( 0.67 vs. 0.52 to 0.57$)$. The estimate for maternal heritability was small and similar to those for the other three breeds (0.03 vs. 0.01 to 0.02 ). With the usual model without interactions, the estimate of fraction of variance due to maternal permanent environmental effects was zero and the estimate of fraction of variance due to animal permanent environmental effects was small (0.02), which was less than for the other three breeds $(0.09$ to 0.12$)$. With the full model, the estimate of the fraction of variance due to dam $\times$ year interaction effects was 0.03 , which was similar to estimates of 0.00 to 0.05 for the other breeds. The estimate of 0.03 was not significant by the LRT or by the standard error of the estimate. The estimate of variance due to effects of sire by cytoplasmic line was nil $(0.00)$ in contrast to fractional estimates of variance of 0.02 to 0.06 for the other breeds.

Estimates for lambs born are given in Table 6. These estimates are within the ranges found for the Columbia, Rambouillet, and Targhee breeds, with an estimate of direct heritability of 0.08 . As with the other traits, there was no evidence of cytoplasmic effects contributing to variation.

\section{Implications}

Cytoplasmic effects need not be considered in genetic evaluations for the four representative traits of Polypay sheep, where the cytoplasmic effects derived from Rambouillet ewes would be expressed in the background of a four-way cross involving Finnsheep, Polled Dorset, Targhee, and Rambouillet. This conclusion is similar to conclusions made previously for the Columbia, Ram- bouillet, and Targhee breeds. Interactions of dam with year or number born or sire contributed to variations in birth weight, as with the other three dual-purpose breeds. Inclusion of these effects in models of analyses, as with the other breeds, had little effect on estimates of direct and maternal heritability, which suggests that ignoring these interactions may not have much effect on rankings by estimated breeding values, but may affect the accuracy of the predictions. Further study is needed to explain the biological mechanisms that create the interaction effects.

\section{Literature Cited}

Al-Shorepy, S. A., and D. R. Notter. 1998. Genetic parameters for lamb birth weight in spring and autumn lambing. Anim. Sci. 67:327-332.

Boldman, K. G., L. A. Kriese, L. D. Van Vleck, C. P. Van Tassell, and S. D. Kachman. 1995. A manual for use of MTDFREML. A set of programs to obtain estimates of variances and covariances [Draft]. USDA-AARS, Clay Center, NE.

Dodenhoff, J., L. D. Van Vleck, S. D. Kachman, and R. M. Koch. 1998. Parameter estimates for direct, maternal and grandmaternal genetic effects for birth weight and weaning weight in Hereford cattle. J. Anim. Sci. 76:2521-2527.

Ercanbrack, S. K., and A. D. Knight. 1998. Responses to various selection protocols for lamb production in Rambouillet, Targhee, Columbia, and Polypay sheep. J. Anim. Sci. 76:1311-1325.

Gibson, J. P., A. E. Freeman, and P. J. Boettcher. 1997. Cytoplasmic and mitochondrial inheritance of economical traits in cattle. Livest. Prod. Sci. 47:115-124.

Hanford, K. J. 2001. Estimates of genetic parameters and genetic change for prolificacy, weight, and wool characteristics of Columbia, Targhee and Polypay sheep. Ph.D. Diss., Univ. of Nebraska, Lincoln.

Hanford, K. J., G. D. Snowder, and L. D. Van Vleck. 2003. Models with nuclear, cytoplasmic, and environmental effects for production traits of Columbia sheep. J. Anim. Sci. 81:1926-1932.

Hulet, C. V., S. K. Ercanbrack, and A. D. Knight. 1984. Development of the Polypay breed of sheep. J. Anim. Sci. 58:15-24.

Maniatis, N., and G. E. Pollott. 2002. Nuclear, cytoplasmic, and environmental effects on growth, fat, and muscle traits in Suffolk lambs from a sire referencing scheme. J. Anim. Sci. 80:57-67.

Smith, S. P., and H.-U. Graser. 1986. Estimating variance components in a class of mixed models by restricted maximum likelihood. J. Dairy Sci. 69:1156-1165.

Snowder, G. D., K. J. Hanford, and L. D. Van Vleck. 2004. Comparison of models including cytoplasmic effects for traits of Rambouillet sheep. Livest. Prod. Sci. 90:159-166.

Van Vleck, L. D., G. D. Snowder, and K. J. Hanford. 2003. Models with cytoplasmic effects for birth, weaning and fleece weights, and litter size at birth for a population of Targhee sheep. J. Anim. Sci. 81:61-67.

Westell, R. A., R. L. Quaas, and L. D. Van Vleck. 1988. Genetic groups in an animal model. J. Dairy Sci. 71:1310-1318. 